\title{
Effectiveness of protected areas for the conservation of aquatic invertebrates: a study-case in southern Brazil
}

Efetividade das áreas protegidas na conservação de invertebrados aquáticos: um estudo de caso no Sul do Brasil

Rozane Maria Restello $^{1 *}$ (D), Daiane Battistoni ${ }^{1}$, Jesse Renan Sobczak ${ }^{1}$, Alice Teresa Valduga ${ }^{1}$, Sônia Beatriz Balvedi Zackrzevski ${ }^{1}$, Elisabete Maria Zanin ${ }^{1}$, Vanderlei Secretti Decian ${ }^{1}$ and Luiz Ubiratan Hepp ${ }^{1}$

'Programa de Pós-graduação em Ecologia, Departamento de Ciências Biológicas, Universidade Regional Integrada do Alto Uruguai e das Missóes - URI, Campus de Erechim, Av. Sete de Setembro, 1621, CEP 99700-000, Erechim, RS, Brasil

*rrozane@uricer.edu.br

Cite as: Restello, R. M., Battistoni, D., Sobczak, J. R., Valduga, A. T., Zackrzevski, S. B. B., Zanin, E. M., Decian, V. S. and Hepp, L. U. Effectiveness of protected areas for the conservation of aquatic invertebrates: a study-case in southern Brazil. Acta Limnologica Brasiliensia, 2020, vol. 32, e5

Abstract: Aim: This work aimed to analyze the effectiveness of protected areas (PA) as maintainers of the fauna of benthic macroinvertebrates and the use of these in the water management of these areas. We tested the hypothesis that in streams located within the PA there will be greater abundance and diversity of organisms. Methods: We collected macroinvertebrates in streams located inside and outside two PA in Southern Brazil: (Fritz Plaumann State Park, Santa Catarina, Teixeira Soares Municipal Natural Park, Rio Grande do Sul). In each stream we measured physical and chemical variables of the water. Three sub-samples of macroinvertebrates were collected on stony substrate with a Surber sampler and calculated abundance of organisms, rarefied richness, Shannon diversity and Evenness. Results: The streams located in the interior of the PA presented well oxygenated waters and slightly basic $\mathrm{pH}$. The electrical conductivity was higher in the external sections than the UC. We observed that rarefied richness, Shannon diversity and equitability were higher in the streams located inside the PA. PerMANOVA indicates that the composition was different between streams sections $(p=0.03)$ and PA $(p=0.01)$. Conclusions: The use of organisms as bioindicators showed a potential response to the environmental integrity of streams. Thus, these organisms have potential for use by PA managers for monitoring and decision making on the maintenance of protected areas.

Keywords: aquatic macroinvertebrates; protected areas; Neotropical region.

Resumo: Objetivo: este trabalho teve por objetivo analisar a efetividade de Áreas Protegidas (AP) como mantenedoras da fauna de macroinvertebrados bentônicos e a utilização destes na gestão das águas dessas áreas. Testamos a hipótese de em riachos localizados dentro das AP haverá maior abundância e diversidade de organismos. Métodos: Coletamos macroinvertebrados em riachos localizados dentro e fora de duas UC no Sul do Brasil: (Parque Estadual Fritz Plaumann, Santa Catarina; Parque Natural Municipal Teixeira Soares, Rio Grande do Sul). Em cada riacho foram mensurados variáveis físicas e químicas da água. Foram coletadas três sub-amostras de macroinvertebrados em substrato pedregoso com um amostrador Surber e calculados abundância de organismos, riqueza rarefeita, diversidade de Shannon e Equitabilidade. Resultados: Os riachos localizados no interior das AP apresentaram águas bem oxigenadas e $\mathrm{pH}$ ligeiramente básico. A condutividade elétrica foi maior nos trechos 
externos as AP. Observamos que riqueza rarefeita, diversidade de Shannon e equitabilidade foram maiores nos riachos localizados no interior das AP. A PerMANOVA nos indica que a composição foi diferente entre trechos dos rios $(p=0,03)$ e PA $(p=0,01)$. Conclusóes: $\mathrm{O}$ uso dos organismos como bioindicadores demostrou potencial de resposta em relação a integridade ambiental dos riachos. Assim, estes organismos têm potencial para utilizaçáo pelos gestores de AP para monitoramento e tomada de decisões sobre a manutenção das áreas protegidas.

Palavras-chave: macroinvertebrados aquáticos; áreas protegidas; Regiáo Neotropical.

\section{Introduction}

In recent decades, aquatic ecosystems have been significantly affected by multiple environmental impacts caused by the expansion of human activities (Budke et al., 2012; Chen et al., 2014; Mendoza et al., 2017). This has caused a disruption of the physical and chemical environment, has altered the natural dynamics of biological communities, led to environmental changes (Callisto et al., 2012; Tejerina \& Malizia, 2012), and has significantly reduced the quality of the water and decreased aquatic biodiversity (Restello et al., 2014). Thus, aquatic ecosystems are among the most threatened ecosystems in the world (Harrison et al., 2016).

The establishment of legally protected areas is one of the strategies adopted worldwide, for protecting and maintaining ecosystems. Brazil contains approximately 1.5 million $\mathrm{km}^{2}$ of protected areas, representing $17.2 \%$ of land areas and inland water, and $1.5 \%$ of ocean areas (Brasil, 2015). Most of these areas have been created to protect terrestrial flora and fauna species and genetic diversity, and to ensure the maintenance of ecosystem services. However, the protected area protects a number of aquatic ecosystems and consequently aquatic species (Agostinho et al., 2005).

In Latin America, most of the parks and protected areas were created to protect the water bodies that supply the human population (Echavarria, 2005). In Brazil, about $1 / 3$ of hydroelectric power plant that are in operation, under construction or awarded and account for $80 \%$ of the country's energy production, pipe water from PA or rivers whose sources or major tributaries are located near to, and downstream from PA (Medeiros \& Young, 2011).

Studies on PA in Brazil, usually refer to the ability to protect the terrestrial fauna and flora (Agostinho et al., 2005; Bensusan, 2015; Harrison et al., 2016). However, studies in PA that aim to evaluate the efficiency of these areas in maintaining aquatic biodiversity are scarce (Teles et al., 2013; Teshima et al., 2015). Recently, some studies have been conducted in streams located inside and outside of PA (usually in the protected area buffer zone) (Silva et al., 2007; Caldeira et al., 2013; Teles et al., 2013; Teshima et al., 2015). These studies have focused on PA in southeastern and northeastern Brazil, demonstrating that watershed sections protected by PA favour the preservation of benthic diversity (Silva et al., 2007; Neves \& Valentin, 2011; Teles et al., 2013; Françoso et al., 2015).

In this study, we assessed (i) whether protected areas are important in maintaining diversity of the benthic macroinvertebrates fauna. We therefore conducted a study in streams associated with two conservation units located in the states of Rio Grande do Sul and Santa Catarina, southern Brazil. We tested the hypothesis that abundance and richness of organisms on inside streams is higt than outside streams. The public managers can use this information to monitor and manage the PA and buffer zones of the conservation units.

\section{Material and Methods}

\subsection{Study area}

This study was conducted in two Protected Areas (PA) within the Atlantic Forest vegetation. The vegetation is characterised by a mixture of Seasonal Evergreen Forest with Araucaria and Seasonal Semi-deciduous Forest (Oliveira-Filho et al., 2015). The Fritz Plaumann State Park (PFP) is located in the municipality of Concordia, Santa Catarina $\left(27^{\circ} 15^{\prime} 20^{\prime \prime}\right.$ and $27^{\circ} 20^{\prime} 15^{\prime \prime}$ S, 52 $04^{\circ} 52^{\prime \prime}$ and $\left.52^{\circ} 09^{\prime} 57^{\prime \prime} \mathrm{W}\right)$ and Teixeira Soares Municipal Natural Park (PTS) is located in the municipality of Marcelino Ramos, Rio Grande do Sul (27026’30" and 27'31'30"S, 51'55'14" and 51'57'36”W) (Figure 1). Both PA are located near the Itá Hydroelectric Plant and were created in the late 1990s. These parks were implemented as a compensatory environmental measure. The water network that drains both PA is composed of small streams and flows primarily into the Uruguay River.

Three samples were collected in each of the 13 sections of stream $(<3$ th order) distributed in both PA were selected: seven sections in the PFP (four inside and three outside the PA limit) in March 2011 and six in the PTS (three inside and three outside the PA limit) in January 2009. 
The outside streams are located in the buffer zone of the PA $(500 \mathrm{~m})$ and all show anthropogenic influence from the surroundings. The characteristic vegetation of PTS and PFP belongs to the Deciduous Seasonal Forest, which is characterized by the great abundance of large deciduous species, especially the family Fabaceae (Socioambiental Consultores Associados, 2012). In the PFP, the main human activities are agriculture and the breeding of pigs and poultry, whereas in the PTS, the main activities are agriculture and tourist development. According to the area management plan in PFP, the main anthropic activities are agriculture and pig and poultry farming (Stamberg et al., 2012), while in PTS the main activities are agriculture and tourism development (Socioambiental Consultores Associados, 2012).

\subsection{Environmental variables and the sampling of benthic macroinvertebrates}

In each section of stream, the water temperature, dissolved oxygen, $\mathrm{pH}$, electrical conductivity, turbidity and total dissolved solids were measured using a multiparameter analyser $\mathrm{Horiba}^{\circledR}$. The methodology for the analysis of parameters follows Apha (1998).

We collected benthic macroinvertebrates with a Surber collector $\left(\right.$ mesh $=250 \mathrm{~mm}$; area $\left.=0.09 \mathrm{~m}^{2}\right)$. We carried three sub-samples per section in each riffle areas on stone substrate. The material was fixed in the field with $80 \%$ ethanol, packed in plastic pots and taken to the laboratory for identification, to family taxonomic level, using stereomicroscope and keys of Fernandez \& Domingues (2001) and Mugnai et al. (2010).

\subsection{Data analysis}

For the analysis of the structure of the assembly we used abundance defined by the number of organisms collected the rarefied richness, Shannon Diversity Index and Evenness. We used the rarefaction technique to avoid potential effects on the taxonomic richness generated by the difference in abundance of organisms collected in the streams. We used Analysis of Variance (two-way ANOVA) to assess the difference of biological metrics and

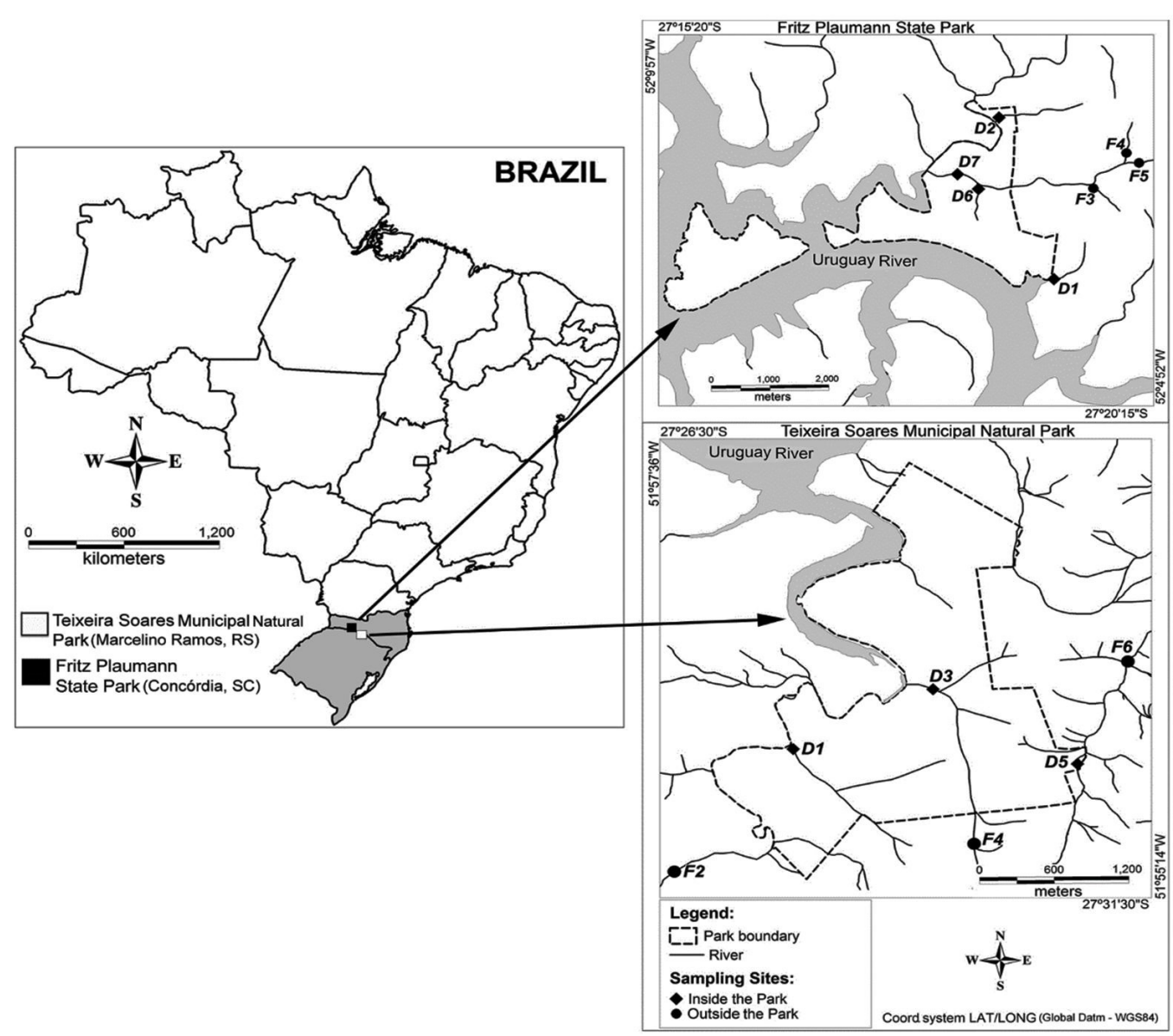

Figure 1. Geographical location of Fritz Plaumann State Park (Concordia, Santa Catarina) and the Teixeira Soares Municipal Natural Park (Marcelino Ramos, Rio Grande do Sul). 
Table 1. Water physicochemical variables in the streams of the protected areas Fritz Plaumann Park (PFP) and Teixeira Soares Park (PTS) in southern Brazil (mean and range).

\begin{tabular}{lcccc}
\hline \multicolumn{1}{c}{ Limnological variables } & Inside (PFP) & Outside (PFP) & Inside (PTS) & Outside (PTS) \\
\hline Water temperature $\left(^{(}\right)$ & $19.77 \pm 0.51$ & $21 \pm 1.00$ & $21 \pm 1.82$ & $19.55 \pm 1.41$ \\
$\mathrm{pH}$ & $7.42 \pm 0.18$ & $7.08 \pm 0.45$ & $7.69 \pm 0.20$ & $6.68 \pm 1.00$ \\
Dissolved Oxygen $\left(\mathrm{mg} \mathrm{L}^{-1}\right)$ & $13.79 \pm 0.63$ & $12.44 \pm 0.08$ & $10.08 \pm 0.57$ & $9.50 \pm 0.70$ \\
Electrical conductivity $\left(\mu \mathrm{S} \mathrm{cm}^{-1}\right)$ & $0.07 \pm 0.02$ & $0.07 \pm 0.04$ & $0.06 \pm 0.00$ & $0.07 \pm 0.01$ \\
Turbidity $(\mathrm{NTU})$ & $23.95 \pm 37.37$ & $4.37 \pm 0.23$ & $3.26 \pm 0.65$ & $3.61 \pm 0.92$ \\
Total dissolved solids $\left(\mathrm{mg} \mathrm{L}^{-1}\right)$ & $0.04 \pm 0.01$ & $0.05 \pm 0.01$ & $0.04 \pm 0.04$ & $0.04 \pm 0.01$ \\
Velocity $\left(\mathrm{m} \mathrm{s}^{-1}\right)$ & $0.23 \pm 0.05$ & $0.19 \pm 0.07$ & $1.10 \pm 0.98$ & $0.47 \pm 0.29$ \\
\hline
\end{tabular}

Table 2. Results of two way ANOVA to verify if the community structure varies between Protect Areas (PA) and between locations inside the PA. df: degree of freedon; SS: sum of square.

\begin{tabular}{lccrc}
\hline & df & SS & F-value & p-value \\
\hline Abundance & & & & \\
Sites & 1 & 0.23 & 0.467 & 0.512 \\
PA & 1 & 0.22 & 0.442 & 0.523 \\
PA: Sites & 1 & 0.08 & 0.015 & 0.905 \\
Residuals & 9 & 4.57 & & \\
Rarefied richness & & & & \\
Sites & 1 & 48.78 & 10.396 & 0.010 \\
PA & 1 & 1.86 & 0.397 & 0.544 \\
PA: Sites & 1 & 11.20 & 2.387 & 0.156 \\
Residuals & 9 & 42.23 & & \\
Shannon Diversity & index & & & \\
Sites & 1 & 0.280 & 25.901 & 0.000 \\
PA & 1 & 0,005 & 0.496 & 0.499 \\
PA: Sites & 1 & 0.081 & 7.295 & 0.024 \\
Residuals & 9 & 0.010 & & \\
Eveness & \multicolumn{5}{c}{} & & \\
Sites & 1 & 0.121 & 25.898 & 0.000 \\
PA & 1 & 0.002 & 0.495 & 0.499 \\
PA: Sites & 1 & 0.034 & 7.299 & 0.024 \\
Residuals & 9 & 0.042 & & \\
\hline & & & & \\
\hline
\end{tabular}

limnological variables between of the PA and the location of the streams (inside and outside). We transform the biological data from a Hellinger transformation and conducted a Permutation Multivariate Analysis of Variance (PerMANOVA, 999 permutations) to assess the differences in community composition between the PAs and the location of streams. Finally, we applied a Principal Coordinate Analysis (PCoA) and calculated the Euclidian distance of the centroid between the sample units of each PA and the location of the streams, to assess the homogeneity of variance of the benthic communities. We then used an ANOVA to assess the significance of the difference in the distances of the centroid. In addition, we conducted a Simper (Bray-Curtis dissimilarities) to evaluate the contribution of each rate considering comparisons between PA and between locations. All analyses were performed with $\mathrm{R}$ software ( $\mathrm{R}$ Development Core Team, 2013) using the functions of the 'vegan' package (Oksanen et al., 2013).

\section{Results}

The environmental variables did not vary between PA and location, except for dissolved oxygen (Table 1). The dissolved oxygen concentrations were higher in PFP and inside PA $\left(F_{(1,9)}=121.3\right.$, $p<0.001$ and $F_{(1,9)}=10.0, p=0.01$; respectively for PA and locations; Table 1). For the other variables, we observed slightly basic $\mathrm{pH}$ water (7.0 to 7.7 ). The electrical conductivity was greater in the streams sections outside PA $\left(>0.07 \mathrm{mS} \mathrm{cm}^{-1}\right)$ (Table 1).

We collected a total of the 2,698 benthic macroinvertebrates in the 13 streams sections inside and outside of the two PA (49.5\% in the PFP, and $50.5 \%$ in the PTS). These organisms were distributed among 30 taxa, represented by the phyla Annelida, Mollusca and Arthropoda (Table A1 Appendix A). The abundance of organisms was similar among sites and between PA (Table 2).

A total of 752 specimens belonging to 25 families were collected in the streams within the PFP and 584 in streams outside the park, belonging to 16 families. In PTS, 19 families were identified inside the park and 12 outside the park. The abundance of organisms was similar among sites and between PA. On the other hand, the Shannon Diversity Index and Evenness was different between locations (inside and outside) and PA. The rarefied richness was different between sites: PFP and PTS, being higher inside the PA (Table 2, Figure 2).

More than $30 \%$ of the organisms in both PA were represented by the Chironomidae family. We collected most of these organisms outside the PA. The Ephemeroptera, Plecoptera and Trichoptera (EPT) aquatic insect orders accounted for $53 \%$ of the total fauna in the PFP and $26 \%$ in the PTS. The most abundant families inside PA were Baetidae and Leptophlebiidae (PFP) and Baetidae and Chironomidae (PTS). The composition was different 

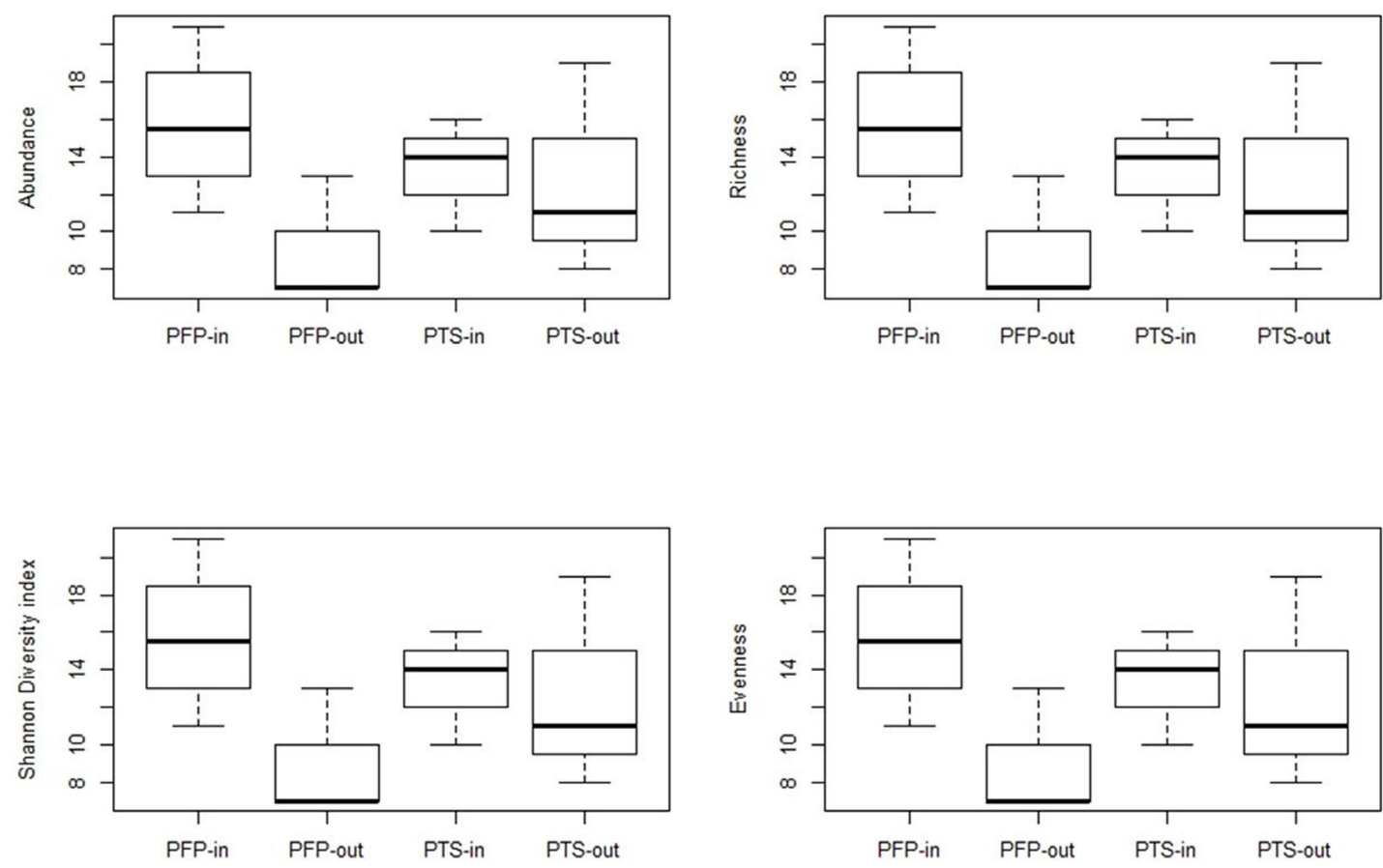

Figure 2. Box Plot of the structure metrics of the benthic macroinvertebrates community in the protected areas Fritz Plaumann Park (PFP) and Teixeira Soares Park (PTS) in southern Brazil. In: PA Inside sections, Out: PA Outside sections.
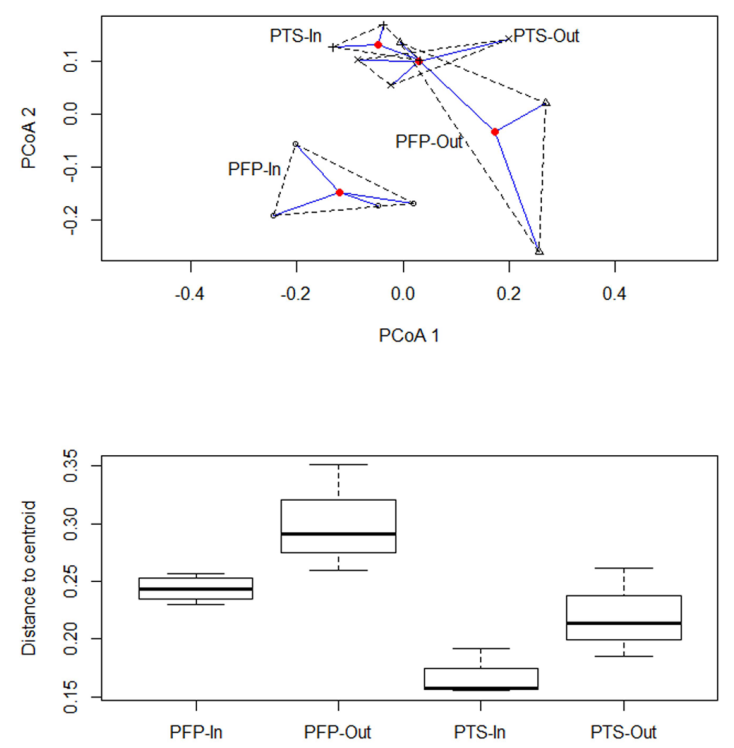

Figure 3. The Principal Coordinates Analysis of the benthic macroinvertebrate community composition and box-plot of the distance to centroid in the protected areas Fritz Plaumann Park (PFP) and Teixeira Soares Park (PTS) in southern Brazil. In: Inside sections, Out: Outside sections.

between local communities $\left(F_{(1,9)}=2.0, p=0.03\right)$ and PA $\left(F_{(1,9)}=2.2, p=0.01\right)$. The variability of the community was higher in streams sections outside PFP (distance to centroid $=0.30$ ) compared to streams sections inside PTS (distance to centroid $=0.16)\left(F_{(3,9)}=9.4, p=0.003\right.$; Figure 3). The variability outside sections was higher than inside sections by two PA (Figure 3).

The Simper analysis showed Simuliidae as the taxa with the greatest contribution to distinguish PA (Simper contribution $=0.054, \mathrm{p}=0.012$ ), specially at PTS. On the other hand, Chironomidae and Hydropsychidae were important for dissimilarity between locations. Chironomidae had the greatest contribution outside (Simper contribution $=0.246$, $\mathrm{p}=0.006$ ), while Hydropsychidae had the greatest contribution inside (Simper contribution $=0.027$, $\mathrm{p}=0.049)$.

\section{Discussion}

Our results demonstrated that the studied PAs are important in maintaining the macroinvertebrates biodiversity of streams in the study area. The observed differences in the rarefied richness, the Shannon Diversity Index, Evenness, and composition of fauna inside and outside of the PA supported this assertion. In addition, we observed that the dominance of Chironomus, which is a bioindicator of impacted sites (high organic matter and eutrophication) (Calle-Martinéz \& Casas, 2006), being therefore considered indicators of polluted streams (Hepp \& Restello, 2007; Kleine \& Trivinho-Strixino, 2005; Oliveira et al., 2010). 
The highest rarefied richness observed in the streams sections located inside the parks is an indication that the protected areas help to maintain the environmental integrity of the sites and favors this condition (Paz et al., 2008; Caldeira et al., 2013). Bueno et al. (2003) suggests that the high richness of organisms is related to good conditions of integrity, suggesting availability of habitats, food sources and niches to be occupied, supporting the survival of organisms.

Another factor that indicates the potential of the PA as maintainers of aquatic biodiversity is the greatest richness in sections located inside sites. Therefore, we confirm that PA help to maintain the local environmental integrity (Paz et al., 2008; Caldeira et al., 2013). According to De Toni et al. (2014), a high abundance and richness of organisms are related to conditions of high integrity, suggesting the availability of habitats and food resources, which support the survival of organisms. In addition, undisturbed environments are characterized by a high diversity and richness and a homogeneous distribution of individuals among the species found (high evenness) (Silveira, 2004). Our results indicate the maintenance of the fauna in streams located within the studied PA.

On the other hand, the decrease in the richness in the outside sites is a warning in terms of management of the PA. The sites located in the buffer zone should be restricted by law (Brasil, 2000). Intense agricultural practices that undermine the environmental quality of these streams were observed. The removal of riparian vegetation reduces the organic matter input into the streams and affects the aquatic fauna (Silva et al., 2007). The Chironomidae family almost always presents itself as dominant, both in lotic and lentic environments, due to its tolerance to extreme situations like hypoxia and its high rate of population growth (Ribeiro \& Uieda, 2005).

We observed an increase of the EPT inside the PA, and a decrease these organisms in outside streams sections. High abundance and richness of these organisms reflect the positive conditions of environmental integrity. Inside the PA, the streambeds are more stable and contain many physical habitats that show no signs of alteration. These conditions contribute to the increase of the diversity and abundance of the EPT organisms (Teles et al., 2013; Ferreira et al., 2015). Besides being present in sites with high concentrations of dissolved oxygen in the water, necessary for their survival. In this way, they are classified as sensitive to environmental changes, and therefore, considered good indicators of the integrity of the lotic environment (Goulart \& Callisto, 2003), and consequently of the conditions of the streams in the interior of the PA under study.

An unexpected result was the variation in composition between the two PA. Because both PAs are inserted into the same vegetation formation, belonging to the same hydrographic basin and are close to each other (about $27.3 \mathrm{~km}$ ), a similar fauna composition was expected. Moreover, the difference in composition between the inside and the outside of the PA was expected.

By Simper's analysis, Simuliidae family contributed to the sites similarity inside and outside the PTS. This is due to the fact that high water oxygen is important for larval development due to metabolic necessity (Coppo \& Lopes, 2010). They show preference for areas with high current flow for laying eggs, a fact observed within the PA. Immatures are relatively tolerant to the presence of large amounts of organic matter and also to variations in $\mathrm{pH}$ and conductivity being intolerant in most cases to pollution, they are also external to PA (Strieder et al., 2006).

Chironomidae, due to their plasticity and adaptation to sites with organic material accumulation (Arimoro et al., 2006), around the sites, contributed to indicate dissimilarity outside the AP. For the other side, Hydropsychidae contributed for internal dissimilarity of PA. They have great variety of behaviors for food acquisition, being represented in all functional categories of macroinvertebrates (Merritt \& Cummins, 2008). The family inhabits the most varied types of aquatic environments (Wiggins, 1996; Nogueira et al., 2011), which explains the internal dissimilarity of PA.

As noted for the community structural metrics, the activities carried out outside the PA were important for the benthic communities. The difference in composition among the PA relates to the intensity of anthropogenic activities in the watershed of the two areas. Activities relating to swine are the main economic activities in the PFP, which have a high pollution potential, given the large number of contaminants generated by the resulting waste and its improper disposal (Seganfredo et al., 2004). In the PTS, agricultural activities are a major source of income for farmers. However, the slope of the terrain makes mechanised agriculture difficult. 
It was verified that the human activities carried out around the PTS, in this case, agricultural activities end up compromising the water quality and consequently the variability of the benthic community. To Stoddard et al. (2006) changes in the composition and abundance of aquatic organisms, can serve as indicators of the influences that the rivers suffer in relation to the agricultural and urban activities of the PA. Corroborating our hypothesis, in the streams located inside the PA, we found greater wealth and abundance of organisms belonging to EPT. These are considered bioindicators of water quality and pollution sensitive (Crisci-Bispo et al., 2007). While in the outside streams sections the PA, we found a greater abundance of organisms that indicate contamination of the streams by anthropic activities, among them Chirnomidae. These are considered to be pollution tolerant and indicators of high organic matter content (Bubinas \& Jagminiené, 2001; Piedras et al., 2006).

Forested streams are generally more heterogeneous, resulting in a variable set of abundant genera; However, non-forest streams are more homogeneous (Siqueira et al., 2015) and thus habitat modification has generated taxonomic homogenization in freshwater ecosystems (Rahel, 2002). There is the same set of genera being more or less abundant. Siqueira et al. (2015) suggests that the composition of aquatic insects in tropical forest streams faces homogenization due to landscape modification. For the author, sites with more homogeneous characteristics filter a similar set of taxa, with similar abundance and thus more homogeneous assemblies.

Based on our results, we can conclude that PA effectively contribute to the conservation of benthic macroinvertebrates and to the maintenance of the health of streams. The creation of PA can be an important and effective tool for the preservation of lotic ecosystems and their biodiversity (Agostinho et al., 2005). However, the mere creation of a PA is not sufficient; it is essential that the technical and scientific information generated by research is used as an input, to provide a theoretical basis for the incorporation of management actions in the PA.

\section{Acknowledgements}

We thank CAPES/PROSUP for the financial support to study. DB received a scholarship from the Scholarship Program of the Support Found for Development of Higher Education in Santa Catarina - FUMDES.

\section{References}

AGOSTINHO, A.A., THOMAZ, S.M. and GOMES, L.C. Conservação da biodiversidade em águas continentais do Brasil. Megadiversidade, 2005, 1, 70-78.

AMERICAN PUBLIC HEALTH ASSOCIATION APHA. Standard methods for the examination of water and wastewater. 20th ed. Washington, APHA, 1998.

ARIMORO, F.O., IKOMI, R.B. and IWEGBUE, C.M.A. Water quality changes in relation to Diptera community patterns and diversity measured at an organic effluent impacted stream in the Niger Delta, Nigeria. Ecological Indicators, 2006, 6(2), 1-12.

BENSUSAN, N. Conservação da biodiversidade em áreas protegidas. Rio de Janeiro: Ed. FGV, 2015.

BRASIL. Ministério do Meio Ambiente. Sistema Nacional de Unidade de Conservação [online]. Brasília: MMA, 2000 [viewed 13 Dec. 2015]. Available from: http:// www.mma.gov.br/areas-protegidas/sistemanacionalde-ucs-snuc

BRASIL. Ministério do Meio Ambiente - MMA. Cadastro Nacional de Unidades de Conservação [online]. Brasília: MMA, 2015 [viewed 24 Aug. 2015]. Available from: http://www.mma.gov.br/ areas-protegidas/cadastro-nacional-de-ucs

BUBINAS, A. and JAGMINIENÉ, I. Bioindication of ecotoxityccording to community structure of macrozoobenthic fauna. Acta Zoologica Lituanica, 2001, 11(1), 90-99. http://dx.doi.org/10.1080/139 21657.2001.10512362.

BUDKE, J., HEPP, L.U., DECIAN, V. and ZANIN, E.M. Influência dos usos da terra sobre a composição e funcionalidade de comunidades de macroinvertebrados bentônicos: integrando processos entre paisagem, interface ribeirinha e comunidades biológicas. In: J.E. SANTOS, E.M. ZANIN and L.E. MOSCHINI, orgs. Faces da Polissemia da Paisagem: ecologia, planejamento e percepção. São Carlos: Rima, 2012.

BUENO, A.A.P., BOND-BUCKUP, G. and FERREIRA, B.D.P. Estrutura da comunidade de invertebrados bentônicos em dois cursos d'água do Rio Grande do Sul, Brasil. Revista Brasileira de Zoologia, 2003, 20(1), 115-125. http://dx.doi.org/10.1590/S010181752003000100014.

CALDEIRA, D.A., LEDA, L.R. and MUGNAI, R. Caracterização da entomofauna aquática de um trecho do rio Taquara no Parque Natural Municipal da Taquara, Duque de Caxias. Saúde \& Ambiente, 2013, 8, 9-18.

CALLE-MARTÍNEZ, D. and CASAS, J.J. Chironomid species, stream classification, and water-quality assessment: the case of 2 Iberian Mediterranean mountain regions. Journal of the North American Benthological Society, 2006, 25(2), 465-472. http:// 
dx.doi.org/10.1899/0887-3593(2006)25[465:CSS CAW]2.0.CO;2.

CALlisto, M., CASTRO, D., MORAIS, L., Hughes, L., Kimura, M., Alves, R., FREITAS, V., GAGLIARDI, L., GUIMARÃES, L.C., GUTiERrEZ, M.A., Ligeiro, R., MIRANDA, R.F., RESENDE, F. and SALES, S.C.M. Gestão eficiente de bacias hidrográficas no Brasil: dificuldades e perspectivas de soluçôes. Natureza \& Conservação, 2012, 10(1), 92-95. http:// dx.doi.org/10.4322/natcon.2012.016.

CHEN, K., HUGHES, R.M., XU, S., ZHANG, J., CAI, D. and WANG, B. Evaluating performance of macroinvertebrate-based predictive and null modeled multimetric indices (MMI) using multiseason and multi-year samples. Ecological Indicators, 2014, 36, 142-151. http://dx.doi.org/10.1016/j. ecolind.2013.07.006.

COPPO, T. L., \& LOPES, J. Diversidade de Simuliidae (Diptera: Nematocera) de três cursos d' água no parque ecológico da Klabin S.A. - Telêmaco Borba, Estado do Paraná. Semina: Ciências Biológicas da Saúde, 2010, 31(1), 3-14.

CRISCI-BISPO, V.L., BISPO, P.C. and FROEHLICH, C.G. Ephemeroptera, Plecoptera and Trichoptera assemblages in two Atlantic Rainforest streams, Southeastern Brazil. Revista Brasileira de Zoologia, 2007, 24(2), 312-318. http://dx.doi.org/10.1590/ S0101-81752007000200007.

DE TONI, K.R., NAVA, D., RESTELLO, R.M., DECIAN, V.S., ROVANI, I. and HEPP, L.U. Integridade da paisagem e sua influência sobre a composição da comunidade de Chironomidae (Diptera) em riachos de pequena ordem. Ecología Austral, 2014, 24, 335-342.

ECHAVARRÍA, M. O financiamento para a conservação das bacias hidrográficas: o Fundo da Água de Quito, Equador. In: S. PAGIOLA, J. BISHOP, and N. LANDELL-MILLS. Mercados para serviços ecossistêmicos: instrumentos econômicos para conservação e desenvolvimento. Rio de Janeiro: Rebraf, 2005.

FERNANDEZ, H.R. and DOMINGUES, E. Guia para la determinación de los artropodos bentónicos Sudamericanos. Tucumán: UNT, 2001.

FERREIRA, V., CASTAGNEYROL, B., KORICHEVA, J., GULIS, V., CHAUVET, E. and GRAÇA, M.A.S. A meta-analysis of the effects of nutrient enrichment on litter decomposition in streams. Biological Reviews of the Cambridge Philosophical Society, 2015, 90(3), 669-688. http://dx.doi.org/10.1111/brv.12125. PMid:24935280.

FRANÇOSO, R.D., BRANDÃO, R., NOGUEIRA, C.C., SALAMONA, Y.B., MACHADO, R.B. and COLLI, G.R. Habitat loss and the effectiveness of protected areas in the Cerrado Biodiversity Hotspot.
Natureza \& Conservação, 2015, 13, 35-40. http:// dx.doi.org/10.1016/j.ncon.2015.04.001.

GOULART, M.D. and CALLISTO, M. Bioindicadores de qualidade de água como ferramenta em estudos de impacto ambiental. Revista FAPAM, 2003, 2, 78-85.

HARRISON, I.J., GREEN, P.A., FARRELL, T.A., JUFFE-BIGNOLI, D., SÁENZ, L. and VÖRÖSMARTY, C.J. Protected areas and freshwater provisioning: a global assessment of freshwater provision, threats and management strategies to support human water security. Aquatic Conservation, 2016, 26, 103-120. http://dx.doi.org/10.1002/ aqc. 2652 .

HEPP, L.U. and RESTELLO, R.M. Macroinvertebrados bentônicos como bioindicadores da qualidade das águas do Alto Uruguai Gaúcho. In: S.B.B. ZARKZEVSKI, org. Conservação e uso sustentável da água: múltiplos olhares. Erechim: Edifapes, 2007, pp. 75-85.

KLEINE, P. and TRIVINHO-STRIXINO, S. Chironomidae and other aquatic macroinvertebrates of a first order stream: community response after habitat fragmentation. Acta Limnologica Brasiliensia, 2005, 17, 81-90.

MEDEIROS, R. and YOUNG, C.E.F. Contribuição das unidades de conservação brasileiras para a economia nacional: relatório final. Brasília: UNEP-WCMC, 2011.

MENDOZA, G., TRAUNSPURGER, W., PALOMO, A. and CATALAN, J. Nematode distributions as spatial null models for macroinvertebrate species richness across environmental gradients: a case from mountain lakes. Ecology and Evolution, 2017, 7(9), 3016-3028. http://dx.doi.org/10.1002/ece3.2842. PMid:28480001.

MERRITT, R.W. and CUMMINS, K.W. An introduction to the aquatic insects of North America. 3rd ed. Dubuque, Iowa: Kendall/Hunt, 2008.

MUGNAI, R., NESSIMIAN, J.L. and BAPTISTA, D.F. Manual de identificação de macroinvertebrados aquáticos do Estado do Rio de Janeiro. Rio de Janeiro: Technical Books, 2010.

NEVES, R.A.F. and VALENTIN, J.L. Revisão bibliográfica sobre a macrofauna bentônica de fundos não-consolidados, em áreas costeiras prioritárias para conservação no Brasil. Arquivos de Ciência do Mar, 2011, 44(3), 59-80.

NOGUEIRA, D.S., CABETTE, H.S.R. and JUEN, L. Estrutura e composição da comunidade de Trichoptera (Insecta) de rios e áreas alagadas da bacia do rio Suiá-Miçú, Mato Grosso, Brasil. Iheringia. Série Zoologia, 2011, 101(3), 173-180. http://dx.doi. org/10.1590/S0073-47212011000200004.

OKSANEN, J., BLANCHET, F.G., KINDT, R., LEGENDRE, P., O'HARA, R.G., SIMPSON, 
G.L., SOLYMOS, P., STEVENS, M.H.H. and WAGNER, H. Vegan: Community Ecology Package. $R$ package version 1.17-0 [online]. Vienna: $\mathrm{R}$ Foundation for Statistical Computing, 2013 [viewed 24 Aug. 2015]. Available from: http://CRAN.Rproject.org $/$ package $=$ vegan

OLIVEIRA, V., MARTINS, R. and ALVES, R. Evaluation of water quality of an urban stream in southeastern Brazil using Chironomidae Larvae (Insecta: Diptera). Neotropical Entomology, 2010, 39(6), 873-878. http://dx.doi.org/10.1590/S1519566X2010000600004. PMid:21271051.

OLIVEIRA-FILHO, A.T., BUDKE, J.C., JARENKOW, J.A., EISENLOHR, P.V. and NEVES, D.R.M. Delving into the variations in tree species composition and richness across South American subtropical Atlantic and Pampean forests. Journal of Plant Ecology, 2015, 8(3), 242-260. http://dx.doi. org/10.1093/jpe/rtt058.

PAZ, A., MORENO, P., ROCHA, L. and CALLISTO, M. Efetividade de áreas protegidas (APs) na conservação da qualidade das águas e biodiversidade aquática em sub-bacias de referência no rio das Velhas (MG). Neotropical Biology and Conservation, 2008, 3(3), 149-158. http://dx.doi.org/10.4013/ nbc.20083.06.

PIEDRAS, S.R.N., BAGER, A., MORAES, P.R.R., ISOLDI, L.A., FERREIRA, O.G.L. and HEEMANN, C. Macroinvertebrados bentônicos como indicadores de qualidade de água na Barragem Santa Bárbara, Pelotas, RS, Brasil. Ciência Rural, 2006, 36(2), 494-550. http://dx.doi.org/10.1590/ S0103-84782006000200020.

R DEVELOPMENT CORE TEAM. $R$ : a language and environment for statistical computing [online]. Vienna: R Foundation for Statistical Computing, 2013 [viewed 3 Feb. 2016]. Available from: http:// www.R-project.org

RAHEL, F.J. Homogenization of freshwater faunas. Annual Review of Ecology and Systematics, 2002, 33(1), 291-315. http://dx.doi.org/10.1146/annurev. ecolsys.33.010802.150429.

RESTELLO, R.M., BIASI, C., MORAES, P.F.M.B., GABRIEL, G. and HEPP, L.U. Composition and diversity of the Chironomidae in subtropical streams: effects of environmental predictors and temporal analysis. Acta Limnologica Brasiliensia, 2014, 26(2), 15-226. http://dx.doi.org/10.1590/ S2179-975X2014000200011.

RIBEIRO, L.O. and UIEDA, V.S. Estrutura da comunidade de macroinvertebrados bentônicos de um riacho de Serra em Itatinga, São Paulo, Brasil. Revista Brasileira de Zoologia, 2005, 22(3), 613-618. http://dx.doi.org/10.1590/S010181752005000300013 .
SEGANFREDO, M.A., RUMJANEK, N.G., XAVIER, G.R. and BARIONI JÚNIOR, W. Visualizando além dos benefícios, na análise do uso dos dejetos de animais como fertilizante. In: Anais do XV Reuniāo Brasileira de Manejo e Conservaçáo do Solo e da Água; Anais do XV Reuniäo Brasileira de Manejo e Conservação do Solo e da Água. Santa Maria: SBCS, 2004.

SILVA, F.L., MOREIRA, D.C., RUIZ, S.S. and BOCHINI, G.L. Avaliação da importância da unidade de conservação na preservaçấo da diversidade de Chironomidae (Insecta: Diptera) no córrego Vargem Limpa, Bauru, Estado de São Paulo. Acta Scientiarum. Biological Sciences, 2007, 29, 401-405.

SILVEIRA, M.P. Aplicaçāo do biomonitoramento para avaliação da qualidade da água em rios. São Paulo: EMBRAPA, 2004.

SIQUEIRA, T., LACERDA, C.G.T. and SAITO, V.S. How does landscape modification induce biological homogenization in Tropical Stream Metacommunities? Biotropica, 2015, 47(4), 509-516. http://dx.doi.org/10.1111/btp.12224.

SOCIOAMBIENTAL CONSULTORES ASSOCIADOS. Plano de Manejo do Parque Natural Municipal Mata do Rio Uruguai Teixeira Soares, Marcelino Ramos. Florianópolis: Consórcio Itá. Tractebel Energia, 2012.

STAMBERG, A.R.P., MONTICELli, C.J., MIRANDA, C.R. and SANTOS FILHO, J.I., orgs. Análise da dinâmica da agricultura no entorno do Parque Estadual Fritz Plaumann, Concórdia, SC. Brasília: Embrapa Suínos e Aves, 2012, Documentos, 153.

STODDARD, J.L., LARSEN, D.P., HAWKINS, C.P., JOHNSON, R.K. and NORRIS, R.H. Setting expectations for the ecological condition of streams: the concept of reference condition. Ecological Applications, 2006, 16(4), 1267-1276. http://dx.doi. org/10.1890/1051-0761(2006)016[1267:SEFTEC] 2.0.CO;2. PMid:16937796.

STRIEDER, M.N., SANTOS, J.E. and VIEIRA, E.M. Distribuição, abundância e diversidade de Simuliidae (Diptera) em uma bacia hidrográfica impactada no sul do Brasil. Revista Brasileira de Entomologia, 2006, 50(1), 119-124. http://dx.doi.org/10.1590/S008556262006000100018.

TEJERINA, E. and MALIZIA, A. Chironomidae (Diptera) larvae assemblages differ along an altitudinal gradient and temporal periods in a subtropical montane stream in Northwest Argentina. Hydrobiologia, 2012, 686(1), 41-54. http://dx.doi. org/10.1007/s10750-011-0984-x.

TELES, H.F., LINARES, M.S., ROCHA, P.A. and RIBEIRO, A.S. Macroinvertebrados bentônicos como bioindicadores no Parque Nacional da Serra 
Restello, R.M. et al.

de Itabaiana, Sergipe, Brasil. Revista Brasileira de Zoociências, 2013, 15, 123-137.

TESHIMA, F.A., FERREIRA, F.C. and CETRA, M. Rarity status of endemic and vulnerable fish species in a Brazilian Atlantic Forest protected area. Natureza \& Conservação, 2015, 13(1), 67-73. http://dx.doi. org/10.1016/j.ncon.2015.04.003.
WIGGINS, G.B. Larvae of the North American Caddisfly Genera (Trichoptera). Toronto: Univesity of Toronto Press, 1996. http://dx.doi.org/10.3138/9781442623606.

Received: 25 November 2016 Accepted: 20 February 2020 
Appendix A. Supplementary material.

Table A1. Abundance of the benthic macroinvertebrates identified in sections located inside (Ins) and outside (Out) the protected areas under study. Three samples in each of the streams sections.

\begin{tabular}{|c|c|c|c|c|c|c|c|c|c|c|c|c|c|}
\hline \multirow{2}{*}{ Taxa } & \multicolumn{7}{|c|}{ Fritz Plaumann State Park } & \multicolumn{6}{|c|}{ Teixeira Soares Municipal Natural Park } \\
\hline & Ins 1 & Ins 2 & Ins 6 & Ins 7 & Out 3 & Out 4 & Out 5 & Ins 1 & Ins 3 & Ins 5 & Out 2 & Out 4 & Out 6 \\
\hline \multicolumn{14}{|l|}{ Annelida } \\
\hline Oligochaeta & 6 & 0 & 3 & 4 & 3 & 0 & 0 & 1 & 0 & 0 & 0 & 0 & 0 \\
\hline \multicolumn{14}{|l|}{ Mollusca } \\
\hline Bivalve & 0 & 0 & 1 & 1 & 0 & 0 & 0 & 0 & 0 & 0 & 0 & 0 & 0 \\
\hline Gastropoda & 0 & 0 & 0 & 0 & 0 & 1 & 0 & 10 & 0 & 1 & 9 & 0 & 0 \\
\hline \multicolumn{14}{|l|}{ Arthropoda } \\
\hline \multicolumn{14}{|l|}{ Arachnida } \\
\hline Acarina & 0 & 0 & 0 & 0 & 0 & 0 & 0 & 0 & 0 & 0 & 1 & 0 & 0 \\
\hline \multicolumn{14}{|l|}{ Crustacea } \\
\hline Amphipoda & 0 & 0 & 0 & 0 & 0 & 0 & 27 & 0 & 0 & 0 & 0 & 0 & 0 \\
\hline \multicolumn{14}{|l|}{ Decapoda } \\
\hline Aeglidae & 4 & 0 & 0 & 0 & 0 & 0 & 0 & 0 & 0 & 1 & 0 & 0 & 0 \\
\hline \multicolumn{14}{|l|}{ Insecta } \\
\hline \multicolumn{14}{|l|}{ Coleoptera } \\
\hline Elmidae & 1 & 5 & 16 & 31 & 0 & 10 & 0 & 36 & 5 & 7 & 21 & 1 & 9 \\
\hline Haliphlidae & 0 & 0 & 0 & 0 & 0 & 0 & 0 & 0 & 0 & 0 & 0 & 1 & 0 \\
\hline Hydrophilidae & 0 & 0 & 0 & 0 & 0 & 0 & 0 & 0 & 0 & 0 & 1 & 0 & 0 \\
\hline Psephenidae & 7 & 0 & 0 & 6 & 0 & 6 & 0 & 3 & 2 & 10 & 1 & 5 & 0 \\
\hline Collembola & 21 & 2 & 1 & 1 & 0 & 1 & 1 & 0 & 0 & 0 & 0 & 0 & 0 \\
\hline \multicolumn{14}{|l|}{ Diptera } \\
\hline Chironomidae & 15 & 5 & 6 & 29 & 74 & 142 & 140 & 113 & 50 & 72 & 157 & 67 & 211 \\
\hline Culicidae & 0 & 0 & 0 & 0 & 0 & 0 & 0 & 0 & 0 & 0 & 2 & 0 & 0 \\
\hline Empididae & 0 & 0 & 0 & 0 & 0 & 1 & 0 & 0 & 0 & 0 & 1 & 0 & 1 \\
\hline Ceratopogonidae & 1 & 0 & 0 & 0 & 0 & 0 & 0 & 0 & 0 & 0 & 0 & 0 & 0 \\
\hline Psychodidae & 0 & 0 & 0 & 3 & 0 & 0 & 0 & 0 & 0 & 0 & 0 & 0 & 0 \\
\hline Simulidae & 0 & 0 & 2 & 5 & 0 & 2 & 0 & 65 & 9 & 6 & 3 & 1 & 74 \\
\hline Tipulidae & 0 & 0 & 0 & 1 & 1 & 0 & 0 & 2 & 0 & 0 & 0 & 0 & 0 \\
\hline \multicolumn{14}{|l|}{ Ephemeroptera } \\
\hline Baetidae & 14 & 10 & 4 & 173 & 0 & 21 & 65 & 55 & 28 & 12 & 30 & 17 & 28 \\
\hline Caenidae & 47 & 5 & 0 & 2 & 1 & 8 & 39 & 1 & 2 & 4 & 13 & 5 & 5 \\
\hline Leptophlebiidae & 13 & 27 & 8 & 107 & 2 & 4 & 20 & 17 & 8 & 8 & 56 & 12 & 11 \\
\hline Oligoneuriidae & 2 & 1 & 1 & 0 & 0 & 0 & 0 & 0 & 0 & 0 & 0 & 0 & 0 \\
\hline \multicolumn{14}{|l|}{ Hemiptera } \\
\hline Aphididae & 0 & 0 & 0 & 0 & 0 & 0 & 0 & 0 & 1 & 0 & 0 & 0 & 0 \\
\hline Hydrometridae & 0 & 0 & 0 & 0 & 0 & 0 & 0 & 0 & 0 & 1 & 0 & 0 & 0 \\
\hline Vellidae & 0 & 0 & 0 & 0 & 0 & 0 & 0 & 0 & 0 & 2 & 0 & 0 & 0 \\
\hline Macrovellidae & 0 & 0 & 0 & 0 & 0 & 0 & 0 & 0 & 0 & 0 & 0 & 0 & 1 \\
\hline Lepidoptera & & & & & & & & & & & & & \\
\hline Pyralidae & 0 & 0 & 0 & 0 & 0 & 0 & 0 & 0 & 0 & 0 & 1 & 0 & 0 \\
\hline Odonata & & & & & & & & & & & & & \\
\hline Coenagrionidae & 0 & 0 & 1 & 0 & 0 & 0 & 0 & 5 & 0 & 4 & 1 & 0 & 0 \\
\hline Gomphidae & 0 & 0 & 2 & 12 & 0 & 5 & 0 & 1 & 0 & 0 & 0 & 0 & 0 \\
\hline Plecoptera & & & & & & & & & & & & & \\
\hline Gripopterygidae & 0 & 0 & 0 & 0 & 0 & 0 & 0 & 0 & 1 & 0 & 0 & 0 & 1 \\
\hline Perlidae & 13 & 15 & 5 & 20 & 5 & 0 & 2 & 1 & 1 & 0 & 4 & 0 & 5 \\
\hline Trichoptera & & & & & & & & & & & & & \\
\hline Glossomatiidae & 0 & 0 & 0 & 0 & 0 & 0 & 0 & 1 & 0 & 0 & 2 & 0 & 0 \\
\hline Helicopsychidae & 0 & 0 & 0 & 1 & 0 & 0 & 0 & 0 & 0 & 0 & 0 & 0 & 0 \\
\hline Hydropsychidae & 12 & 7 & 6 & 34 & 1 & 1 & 0 & 11 & 5 & 4 & 3 & 0 & 27 \\
\hline Hydroptilidae & 0 & 0 & 1 & 4 & 0 & 0 & 0 & 0 & 0 & 0 & 0 & 0 & 0 \\
\hline Leptoceridae & 0 & 0 & 0 & 1 & 0 & 0 & 0 & 0 & 0 & 0 & 0 & 0 & 0 \\
\hline Philopotamidae & 1 & 0 & 1 & 1 & 0 & 0 & 0 & 2 & 0 & 1 & 1 & 0 & 0 \\
\hline Polycentropodidae & 1 & 2 & 1 & 2 & 0 & 1 & 0 & 0 & 0 & 0 & 1 & 0 & 1 \\
\hline Total abundance & 158 & 79 & 59 & 438 & 87 & 203 & 294 & 324 & 112 & 133 & 308 & 109 & 374 \\
\hline
\end{tabular}

